\title{
Cattle grazing behavior on a foothill elk winter range in southeastern Wyoming
}

\author{
R.H. HART, K.W. HEPWORTH, M.A. SMITH, AND J.W. WAGGONER, JR.
}

\begin{abstract}
Cattle at a light stocking rate of 0.17 to $0.18 \mathrm{AUM} / \mathrm{ha}$ over a 35-day grazing season in summer preferred to graze on lowland range sites, while elk in winter preferred upland range sites. We changed stocking rates on the same pastures to a moderate rate of $0.28 \mathrm{AUM} / \mathrm{ha}$ and a very light rate of $0.034 \mathrm{AUM} / \mathrm{ha}$ to determine the effects of stocking rate on cattle preference for range sites and possible habitat overlap between cattle and elk. At all stocking rates, cattle spent significantly more time grazing on loamy range sites and less time on other sites than would be expected on the basis of area occupied by the sites. When grazing pressure was increased from light to moderate, cattle grazing time on loamy sites increased. When grazing pressure was decreased from light to very light, cattle grazed only loamy and shallow sites to the complete exclusion of other sites. Cattle grazed farther from water as stocking rate increased and as the grazing season progressed. They also grazed on steeper slopes as stocking rate increased, and as the season progressed under the highest stocking rate. Even at the highest stocking rate studied, there was little habitat overlap between cattle and elk.
\end{abstract}

Key Words: cattle-elk competition, range sites, stocking rate

\footnotetext{
Authors are range scientist, USDA. Agricultural Research Service, Cheyenne, Wyoming 82009; former research assistant, Division of Range Management, University of Wyoming, Laramie 80271; animal nutritionist, Animal Science Department, University of Wyoming; and associate professor, Division of Range Management, University of Wyoming, respectively.

Manuscript accepted 26 April 1990.
}

Cattle (Bos taurus) distribution is influenced by slope (Mueggler 1965, Roath and Krueger 1982, Ganskopp and Vavra 1987); vertical and horizontal distance to water (Valentine 1947, Miller and Krueger 1975, Low et al. 1981 and 1982); and climatic factors such as ambient temperature, wind speed and direction, humidity, precipitation, and barometric pressure (Arnold and Dudzinski 1978, Miller 1983). Slope and climate are uncontrollable; distance to water can be controlled if other than natural sources of water can be developed.

Manipulations of pasture size, animal density or stocking rate, and length of grazing period in rotational grazing systems are generally thought to improve distribution and reduce forage selectivity (Hormay and Talbot 1961, Denny et al. 1974, Denny and Barnes 1977, Heitschmidt and Walker 1983). It is not entirely accepted, however, that an increase in stocking rate or density will reduce selective tendencies (Streeter et al. 1968, Reece 1983). Cattle on the Wyoming foothill range discussed in this paper preferred certain range sites at a low stocking rate (Pinchak et al. 1991). Our interest was in determining if higher cattle stocking rate would result in reduced selectivity or more widespread grazing distribution.

Cattle and elk (Cervus elaphus) both use foothill ranges and prefer similar plants, but elk generally do not graze foothill pastures at high enough density in summer to compete directly with cattle for forage (Julander and Jeffery 1964, Nagle and Harris 1966). They do, however, concentrate on foothill pastures in winter months when cattle generally are not present (Ward et al. 1973, 1976, and 1980; Oedekoven and Lindzey 1987). This presents the 
possibility of competition because cattle may consume in summer the forage that elk need in the winter. The severity of overlap could depend on cattle stocking rate and feeding distribution during the summer grazing period.

The Wyoming Game and Fish Department's Wick Brothers Management Unit, near Elk Mountain in southeastern Wyoming, offered a location to determine effects of various cattle stocking rates on summer distribution of cattle on an area where winter distribution of elk was known (Ward et al. 1976 and 1980). Summer cattle distribution under light stocking (0.17 to 0.18 animal-unit months [AUM] per ha) was determined by Pinchak et al. (1991). We increased the stocking rate on 1 pasture used by Pinchak and reduced it on the other, creating a study design with baselıne pretreatment data and spatial control to identify changes not caused by treatment. Our study design allowed us to test whether an increase in beef cattle stocking rate caused a change in cattle distribution. The following objectives were identified: (1) Determine the impact of stocking rate on cattle grazing distribution on different range sites and slopes and at different distances from water, and (2) Compare summer cattle distribution patterns with elk winter grazing distribution.

\section{Study Area}

The Wick Brothers Management Unit extends approximately 8 $\mathrm{km}$ west and northwest from Arlington, Wyo. The 4,597-ha area was purchased in 1965 because of its value as critical elk winter habitat. A variety of topography exists on the unit including high rolling hills and benches descending in elevation from 2,714 to 2,214 m along Foote, Wagonhound, and Mule Creeks, all perennial streams (Fig. 1).

The area is on a precipitation gradient between high plains and mountain regions. Annual precipitation averages $397 \mathrm{~mm}$ at Elk Mountain, $10 \mathrm{~km}$ west of the Wick Unit. Precipitation amounts for 1984 and 1985 were 362 and $294 \mathrm{~mm}$, respectively. Precipitation occurs mostly as snow and spring rain. Twenty-year average

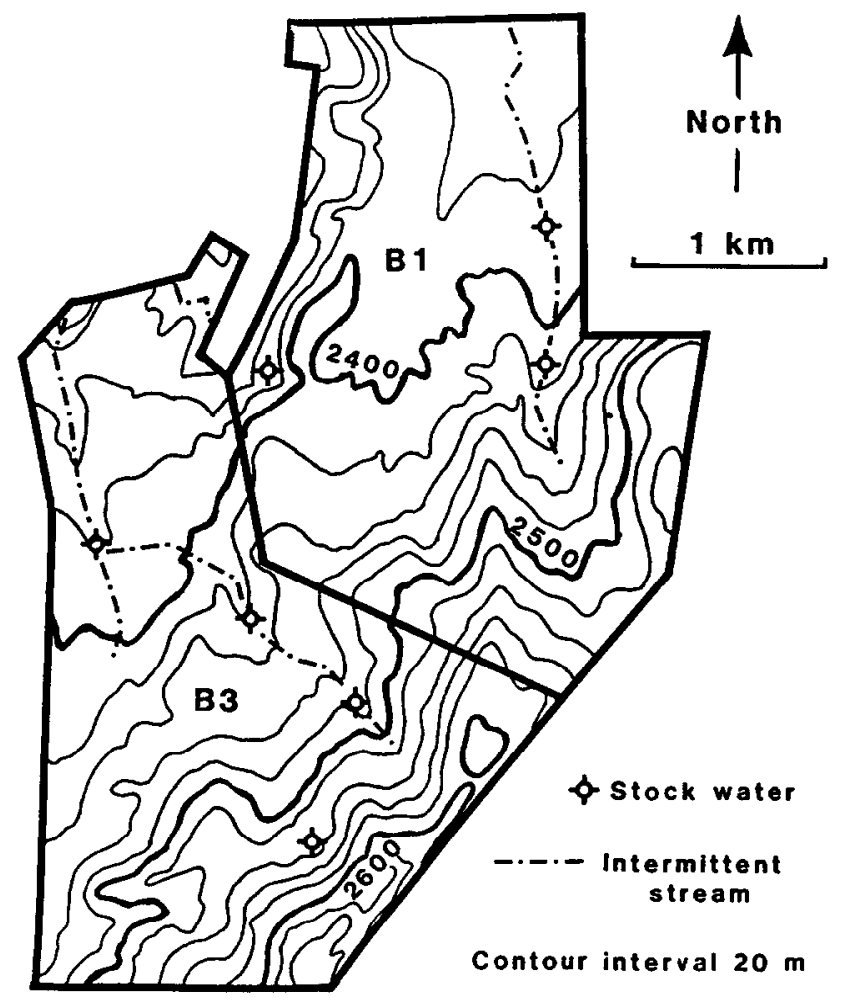

Fig. 1. Contour map of study site. temperatures are $-3.0^{\circ} \mathrm{C}$ for November through March, $6.2^{\circ} \mathrm{C}$ for April and May, $15.0^{\circ} \mathrm{C}$ for June through September, and $6.7^{\circ} \mathrm{C}$ for October. The 20-year average frost-free period is $84 \pm 15$ days.

Livestock were excluded from the study site from 1965 to 1967 ; various levels of livestock grazing were permitted from 1968 to 1978. In 1979, the University of Wyoming obtained a 10-year grazing and hay lease. The grazing permit was from 15 June to 15 October, with a maximum of 800 animal unit months (AUM) allowed. In 1980 a deferred rotation grazing system was implemented. Pastures designated B1 (612 ha) and B3 (563 ha) were used by Pinchak et al. (1991) for this study.

In pastures $\mathrm{B} 1$ and $\mathrm{B} 3,7$ major range sites were delineated and the flora described (Table 1). A map of these range sites was

Table 1. Range sites, forage production in favorable years, and major plant species.

\begin{tabular}{|c|c|}
\hline $\begin{array}{l}\text { Range site } \\
\text { (Production, kg/ha) }\end{array}$ & $\begin{array}{l}\text { Major species according to SCS Technical Guide } \\
\text { (SCS 1988) }\end{array}$ \\
\hline $\begin{array}{l}\text { Loamy } \\
(1,800)\end{array}$ & $\begin{array}{l}\text { Griffiths wheatgrass (Agropyron albicans Scribn. \& } \\
\text { Smith var. griffithsii [Scribn. \& Smith] Beetle) } \\
\text { Slender wheatgrass (Agropyron trachycaulum } \\
\text { [Link] Malte } \\
\text { Idaho fescue (Festuca idahoensis Elmer) } \\
\text { King spikefescue (Leucopoa kingii [Wats.] Weber) }\end{array}$ \\
\hline
\end{tabular}

Grazable Mountain bromegrass (Bromus marginatus Nees) woodland Elk sedge (Carex geyeri Boott) (Unknown) Canby bluegrass (Poa canbyi [Scribn.] Piper)

Wetland/sub- Nebraska sedge (Carex nebraskensis Dewey) irrigated Tufted hairgrass (Deschampsia caespitosa [L.] $(5,400 / 3,900) \quad$ Beauv.)

Shallow loamy Prairie junegrass (Koeleria cristata [L.] Beauv.) $(1,080) \quad$ Mutton bluegrass (Poa fendleriana [Steud.] Vasey) Griffiths wheatgrass

Very shallow Bluebunch wheatgrass (Agropyron spicatum (540)

[Pursh] Scribn. \& Smith)

King spikefescue

Coarse uplands Idaho fescue

$(1,500) \quad$ Prairie junegrass

published by Pinchak et al. (1991). Wetland and subirrigated sites were grouped together for analysis purposes, because they occur in close proximity to each other and are not easily differentiated visually.

Rocky Mountain elk, mule deer (Odocoileus hemionus), and pronghorn antelope (Antilocapra americana) were the native ungulates found on the unit. Approximately 200 mule deer were present all year. Approximately 200 pronghorn occupied the area for 7 to 8 months while as many as 600 elk made use of the unit in winter (Wyoming Game and Fish Department, personal communication).

\section{Methods}

\section{Cattle Observations}

Pastures B1 and B3 were stocked at 153 animal units (AU; 72 cow-calf pairs and 108 yearlings) and $17 \mathrm{AU}$ (8 pairs and 12 yearlings), respectively. Crossbred beef cattle were used in the study. The pairs were part of the University of Wyoming's permanent cow herd while most of the yearlings (steers and heifers) were purchased from order buyers for this study. Grazing periods for the study pastures were 15 June to 20 July 1984 (35d) and 12 July to 14 August 1985 (33 d). Stocking rates on Bl and B3, respectively, were 0.29 and 0.035 animal-unit-months (AUM) per ha in 1984 and 0.28 and $0.033 \mathrm{AUM} / \mathrm{ha}$ in 1985. Pinchak et al. (1991) used stocking rates of 0.17 to $0.18 \mathrm{AUM} / \mathrm{ha}$. 
Table 2. Observed and expected use by range sites, 1981-82 (first 5 weeks only; Pinchak et al. 1991) and 1984-85.

\begin{tabular}{|c|c|c|c|c|c|c|}
\hline \multirow[t]{2}{*}{ Site } & $\begin{array}{c}1981-2 \\
0.18 \\
\text { AUM/ha }\end{array}$ & $\begin{array}{c}\text { Pasture B1 } \\
1984-5 \\
0.28 \\
\text { AUM/ha }\end{array}$ & $\cdots \cdots$ & $\begin{array}{c}1981-2 \\
0.18 \\
\text { AUM/ha }\end{array}$ & $\begin{array}{c}\text { Pasture B3 } \\
1984-5 \\
0.034 \\
\text { AUM/ha }\end{array}$ & $\ldots . . . . . .$. \\
\hline & \multicolumn{6}{|c|}{ (1) } \\
\hline Loamy & $43 b$ & $71 \mathrm{a}^{*}$ & 10 & $46 \mathrm{~b}$ & $81 \mathrm{a}$ & 16 \\
\hline Shallow loamy & $20 \mathrm{a}$ & $13 a^{*}$ & 41 & $36 \mathrm{a}$ & $19 a^{*}$ & 48 \\
\hline Wetland/subirrigated & $21 \mathrm{a}$ & $10 \mathrm{~b}$ & 3 & $6 \mathrm{bc}$ & $0 c$ & 1 \\
\hline Grazable woodland & $10 \mathrm{ab}$ & $<1 \mathrm{ab} *$ & 7 & $10 \mathrm{a}$ & $0 b^{*}$ & 9 \\
\hline Coarse uplands & $2 \mathrm{ab}$ & $5 a^{*}$ & 27 & $2 \mathrm{ab}$ & $0 b^{*}$ & 25 \\
\hline Very shallow & $3 a$ & $1 a^{*}$ & 12 & $<$ la & $0 \mathrm{a}$ & 1 \\
\hline
\end{tabular}

${ }^{a, b}$ Observations on the same site, followed by the same letter, are not significantly different.

- 1984-85 observations are significantly different from expected (Exp.)

Cattle distribution patterns were obtained by riding over each pasture twice daily and mapping the location and activity of all cattle, 2 or 3 days a week, during the grazing period. The pastures were so large and the topography so diverse it was not possible to observe all the cattle in 1 pasture simultaneously. Riding each pasture twice occupied almost the entire day.

Cattle locations were mapped and slope and distance from water at each location determined on USGS topgraphic maps (1:24,000 scale) using a 1,000-m Universal Transverse Mercator Grid. Each individual observation of cattle was converted into animal use days (AUD) for each range site by summing the number of cattle observed grazing each site during an observation period. Percent AUD for each week was determined by dividing the number of cattle observed during that week on a site, by the total number observed on all sites.

Weekly means of the percent of total AUD's observed on each site were analyzed by 3-way analysis of variance (ANOVA), with the 4 pasture-stocking rate combinations (from 1981 and 1982, B1 and B3 at 0.18 AUM/ha [Pinchak et al. 1991]; from 1984 and 1985, $\mathrm{B} 1$ and $0.28 \mathrm{AUM} / \mathrm{ha}$ and $\mathrm{B} 3$ at $0.034 \mathrm{AUM} / \mathrm{ha}$ ] and the 5 weeks of grazing as main effects, and years treated as samples. Data from each range site were analyzed separately. Observed use of range sites within pastures was compared to expected (on the basis of area occupied) use by chi-square analysis with a Bonferroni $Z$ simultaneous confidence interval (Neu et a. 1974, Byers et al. 1984).

In 1984 and 1985 , weekly means of average percent slope, average distance from water, and percent of observations within 300 or $460 \mathrm{~m}$ from water were analyzed by 3-way ANOVA, with pastures and weeks as main effects and years as replications.

Where ANOVA indicated significant differences among means of factors with more than 2 levels, the Neuman-Keuls multiple range test for mean separation (Ott 1984) was used. The 0.05 significance level was chosen for all means except the mean $X$ pasture means for percent slope, for which the 0.10 level was chosen.

\section{Results and Discussion}

\section{Range Site Use}

The majority of animal-use days in 1984-85, 76\%, was observed on loamy range sites that constituted only $13 \%$ of the land area in the pastures (Table 2). An additional 16\% of use-days occurred on the shallow loamy site, which occupied $44 \%$ of the pasture area. Use of the loamy site was significantly greater than expected, on the basis of the area occupied by this site on both pastures, but shallow loamy sites were used less than expected. Wetland/subirrigated sites were used about as expected. All other sites were used much less than expected, except for very shallow sites in the very lightly stocked pasture B3, where they occupied only $1 \%$ of the area.

Under moderate stocking (pasture B1), use of wetland/subirri- gated and coarse upland sites was greater than under very light stocking (pasture B3). At low stocking rates on B3, cattle may have had sufficient feed on the dryer loamy and shallow loamy sites to enable them to avoid the more insect-infested wetland/subirrigated site. Cattle, horses, and other herbivores avoid areas of high insect densities if possible (Arnold and Dudzinski 1978, Keiper and Burger 1983). No differences in use between pastures-stocking rates were observed on the other sites.

Under moderate stocking on B1 in 1984-85, more use was observed on loamy sites and less on wetland/subirrigated sites than under light stocking on the same pasture in 1981-82 (Pinchak et al. 1991). Under very light stocking on $B 3$ in 1984-85, all observed use occurred on loamy and shallow loamy sites, while use was observed on all sites on B3 under light stocking in 1981-82. This concentration on only 2 sites in 1984-85 produced an increase in use on loamy sites in spite of the reduced stocking rate.

It was possible to calculate effective stocking rate on each range site by multiplying stocking rate on the entire pasture by the fraction of total use on that pasture located on that range site, then dividing the product by the fraction of total pasture area occupied by the site. These effective stocking rates then were compared to recommended stocking rates for each site (SCS 1988; Table 3). On

\section{Table 3. Recommended (SCS 1988) and observed stocking rates on range sites within pastures, 1981-82 and 1984-85.}

\begin{tabular}{|c|c|c|c|c|}
\hline Site & $\begin{array}{l}\text { Recom- } \\
\text { mended }\end{array}$ & $\begin{array}{c}-.-- \\
\text { B1 }\end{array}$ & $\begin{array}{c}\text { bserved } \\
35---- \\
\text { B3 }\end{array}$ & $\begin{array}{l}1981-82 \\
\text { B1 \& B3 }\end{array}$ \\
\hline & \multicolumn{4}{|c|}{$\ldots \ldots-\ldots$ AUM/ha $-\ldots \ldots$} \\
\hline Loamy & 0.75 & 1.99 & 0.17 & 0.61 \\
\hline Shallow loamy & 0.42 & 0.09 & 0.01 & 0.11 \\
\hline Wetland/subirrigated & 5.00 & 0.93 & 0.00 & 1.26 \\
\hline Grazable woodland & NL & $<0.01$ & 0.00 & 0.22 \\
\hline Coarse uplands & 0.62 & 0.05 & 0.00 & 0.01 \\
\hline Very shallow & 0.30 & 0.02 & 0.00 & 0.06 \\
\hline
\end{tabular}

NL = Not listed in SCS (1988).

loamy sites, the effective stocking rate in 1981-82 was only slightly lower than the recommended rate, but under heavier stocking in 1984-85, the effective rate was 2.65 times the recommended rate. Effective rates on loamy sites at the lower stocking rate in 1984-85, and on all other sites at all stocking rates, were much lower than recommended. In pastures containing widely differing range sites, it may not be possible to achieve recommended use on lessdesirable sites without dangerous overuse of more-desirable sites.

\section{Cattle Distribution and Distance to Water}

On pasture B1, approximately 16 and $30 \%$ of the total area was within 300 and $460 \mathrm{~m}$ of water, respectively; comparable figures for pasture B3 were 20 and 35\%. In 1984-85, 47\% of animal use was 
observed within $300 \mathrm{~m}$ of water, with no differences between pastures. Significantly more use occurred within $460 \mathrm{~m}$ of water on the very lightly stocked B3 than on the moderately stocked B1,90\% vs. $63 \%$. Under light stocking rates in $1981-82,54 \%$ and $76 \%$ of use was observed within 300 and $460 \mathrm{~m}$, respectively, with no differences between pastures (Pinchak et al. 1990).

Cattle in the moderately stocked Bl were seen to graze an average of $0.53 \mathrm{~km}$ from water vs $0.27 \mathrm{~km}$ in the very lightly stocked B3 (Table 4). Both comparisons suggest that cattle were

Table 4. Mean distance cattle grazed from water $(\mathrm{km})$, 1984-85.

\begin{tabular}{cccc}
\hline \hline $\begin{array}{l}\text { Week of } \\
\text { Grazing }\end{array}$ & $\begin{array}{c}\text { Pasture B1 } \\
\mathbf{0 . 2 8} \text { AUM/ha }\end{array}$ & $\begin{array}{c}\text { Pasture B3 } \\
\text { 0.034 AUM/ha }\end{array}$ & Mean \\
\hline 1 & 0.41 & 0.17 & $0.29 \mathrm{~b}$ \\
2 & 0.46 & 0.32 & $0.39 \mathrm{ab}$ \\
3 & 0.40 & 0.32 & $0.36 \mathrm{ab}$ \\
4 & 0.56 & 0.21 & $0.38 \mathrm{ab}$ \\
5 & 0.83 & 0.34 & $0.58 \mathrm{~b}$ \\
Mean & $0.53 \mathrm{x}$ & $0.27 \mathrm{y}$ & \\
\hline
\end{tabular}

${ }^{a, x}$ Means of weeks or pastures followed by different letters are significantly different.

forced to graze farther from water at higher stocking rates. Hodder and Low (1978), Roath and Krueger (1982), and Bryant (1982) reached similar conclusions. Average distance from water to grazing increased as the grazing season advanced and forage near water diminished, from $0.29 \mathrm{~km}$ in week 1 to $0.58 \mathrm{~km}$ in week 5 .

\section{Cattle Distribution and Slope}

Average percent slope grazed ranged from 2.5 to $6.8 \%$ during the 5 weeks of this study in 1984-85. Slopes used by cattle in pasture B3 averaged $3.2 \%$, vs. $5.2 \%$ in the more heavily stocked $B 1$ pasture (Table 5). Percent slope used in $B 1$ increased from $4.2 \%$ in week 1

Table 5. Mean percent slope used by grazing cattle, 1984-85.

\begin{tabular}{ccc}
\hline \hline $\begin{array}{l}\text { Week of } \\
\text { grazing }\end{array}$ & $\begin{array}{c}\text { Pasture Bl } \\
0.28 \mathrm{AUM} / \mathrm{ha}\end{array}$ & $\begin{array}{c}\text { Pasture B3 } \\
0.034 \mathrm{AUM} / \mathrm{ha}\end{array}$ \\
\hline 1 & $4.2 \mathrm{~cd}$ & $3.0 \mathrm{ab}$ \\
2 & $3.8 \mathrm{bcd}$ & $3.0 \mathrm{ab}$ \\
3 & $4.7 \mathrm{~d}$ & $4.2 \mathrm{~cd}$ \\
4 & $6.8 \mathrm{e}$ & $2.5 \mathrm{a}$ \\
5 & $6.8 \mathrm{e}$ & $3.2 \mathrm{abc}$ \\
Mean & $5.2 \mathrm{x}$ & $3.2 \mathrm{y}$ \\
\hline
\end{tabular}

a,x Means of pastures and pastures $x$ weeks followed by different letters are significantly different.

to $6.8 \%$ in week 5, while slopes used in B3 did not vary from week to week. Pinchak et al. (1991) found 86\% of observed grazing occurred on slopes less than 7\%, and Berg and Hudson (1982) observed $71 \%$ of cattle use on slopes less than $10 \%$. In Utah, Van Vuren (1982) noted 33\% of the land received only $10 \%$ of the use because of steep slopes.

\section{Cattle vs. Elk Site Use}

On the Wick Unit, elk in the winters of 1973 to 1978 preferred coarse upland sites on steep slopes and ridgetops at all snow depths, with some use occurring on very shallow and shallow loamy sites at various snow depths (Ward et al. 1976 and 1980). During 2 winters on foothill range in southwestern Wyoming, 44 and $60 \%$ of elk observations were on steep slopes, ridgelines, and hilltops; 16 and $14 \%$ were on gentle and toeslopes; and 40 and $20 \%$ were on flat land or drainages (Oedekoven and Lindzey 1987). In winter loamy and wetland/subirrigated sites are the first to be covered with snow and rendered unavailable to wintering elk.

Cattle grazing on the Wick Unit in summer at 0.17 to 0.18 $\mathrm{AUM} /$ ha preferred low-lying loamy, shallow loamy, and wetland/ subirrigated sites in 1981-82 and 1984-85. Coarse upland, very shallow, and shallow loamy sites incurred 3,6 , and $26 \%$ of total cattle use, respectively, in 1981-82 (Pinchak et al. 1991). We did not observe an increase in cattle use on these range sites when we increased stocking rate to $0.28 \mathrm{AUM} / \mathrm{ha}$; use on the same sites was 2,3 , and $17 \%$ in $1984-85$.

We established that cattle in summer are most often found on relatively level lowland sites. It has been shown that elk in winter are most often found on steep upland sites. It appears that little habitat overlap exists between these 2 species, either in time or space. However, it must be emphasized that at no time during our study were elk and cattle both present. Cattle were on the range only in summer, and elk only in winter.

\section{Literature Cited}

Arnold, G.W., and M.L. Dudzinki. 1978. Ethology of free-ranging domestic livestock. Elsevier Sci. Publ. Co, New York.

Berg, B.P., and R.J. Hudson. 1982. Elk, mule deer and cattle: Functional interactions on foothills range in southwestern Alberta. p. 509-579. In: J.M. Peek and P.D. Dalke (eds.) Wildlife-Livestock Relationships Symp. Proc. 10. Univ. of Idaho Forest, Wildlife and Range Exp. Sta., Moscow, Idaho.

Bryant, L.D. 1982. Response of livestock to riparian zone exclusion. J. Range Manage. 35:780-785.

Byers, C.R., R.K. Steinhorst, and P.R. Krausman. 1984. Clarification of a technique for analysis of utilization-availability data. J. Wildl. Manage. 48:1050-1052.

Denny, R.P., and D.L. Barnes. 1977. Trials of multi-paddock grazing systems on veld. 3. A Comparison of six grazing procedures at two stocking rates. Rhod. J. Agr. Res. 15:129-142.

Denny, R.P., D.I.. Barnes, and M.F. Franklin. 1974. Some effects of varying the duration, frequency, and intensity of grazing on the growth of steers on veld. Proc. Grassld. Soc. S. Afr. 9:133-137.

Ganskopp, D., and M. Vavra. 1987. Slope use by cattle, feral horses, deer, and bighorn sheep. Northwest Sci. 60:74-81.

Heitschmidt, R.K., and J. Walker. 1984. Short duration grazing and the Savory grazing method in perspective. Rangelands 5:147-150.

Hodder, R.M., and W.A. Low. 1978. Grazing distribution of free-ranging cattle at three sites in the Alice Springs district, Central Australia. Aust. Rangel. J. 1:95-96.

Hormay, A.L., and M.W. Talbot. 1961. Rest-rotation grazing-a new management system for perennial bunchgrass ranges. USDA Prod. Res. Rep. 51.

Julander, O., and D.E. Jeffery. 1964. Deer, elk and cattle range relations on summer range in Utah. Trans. North Amer. Wildl. and Natur. Res. Conf. 29:404-414.

Keiper, R.R., and J. Berger. 1983. Refuge-seeking and pest avoidance by feral horses in desert and island environments. J. Appl. Ethol. 9:11 1-120.

Low, W.A., R.L. Tweedie, C.B.H. Edwards, R.M. Hockler, K.W.J. Malfent, and R.B. Cunningham. 1981. Influence of environment on daily maintenance behavior of free-ranging shorthorn cows in Central Australia. I. General introduction and descriptive analysis of day-long activities. J. Appl. Anim. Ethol. 7:11-26.

Low, W.A., R.L. Tweedie, C.B.H. Edwards, R.H. Hockler, K.W.J. Malfent, and R.B. Cunningham. 1982. Influence of environment on daily maintenance behavior of free-ranging shorthorn cows in Central Australia. II. Multivariate analysis of duration and incidence of activities. $J$. Appl. Anim. Ethol. 8:27-38.

Miller, R. 1983. Habitat use by feral horses and cattle in Wyoming's Red Desert. J. Range Manage. 36:195-198.

Miller, R.F., and W.C. Krueger. 1975. Cattle use on summer foothill ranges in northwestern Oregon. J. Range Manage. 29:367-371.

Mueggler, W.F. 1965. Cattle distribution on steep slopes. J. Range Manage. 18:255-257.

Nagle, J.P., and G.A. Harris. 1966. Grazing compatibility of cattle and elk on mountain ranges. Proc. Internat. Grassl. Congr. 10:994-997.

Neu, C.W., C.R. Byers, and J.M. Peek. 1974. A technique for analysis of utilization-availability data. J. Wildl. Manage. 38:541-545.

Oedekoven, 0.0., and F.G. I.indzey. 1987. Winter habitat-use patterns of elk, mule deer, and moose in southwestern Wyoming. Great Basin Natur. 47:638-643.

Ott, L. 1984. An introduction to statistical methods and data analysis. PWS Publishers, Boston, Mass. 
Pinchak, W.E., M.A. Smith, R.H. Hart, and J.W. Waggoner Jr. 1991. Beef cattle grazing distribution patterns on foothill range. J. Range Manage. 44:267-275

Reece, P.E. 1983. Vegetation and animal response to high intensity-short duration grazing on native range in western Nebraska. Range and Forage Highlights, Univ. of Nebraska Agron. Dept. 1:66-67.

Roath, L.R., and W.C. Krueger. 1982. Cattle grazing and behavior on forested range. J. Range Manage. 35:332-338.

Soil Conservation Service. 1988. Technical guide Section IIE. Major land resource area 34, 10- $14^{\prime \prime}$ precipitation zone, High Plains Southeast. USDA Soil Conserv. Serv. Casper, Wyo.

Streeter, C.L., D.C. Clanton, and O.E. Hoehne. 1968. Influence of advance in season on nutritive value of forage consumed by cattle grazing western Nebraska native range. Nebraska Agr. Exp. Sta. Bull. 227..

Valentine, K.A. 1947. Distance from water as a factor in grazing capacity of rangeland. J. Forest. 45:749-754.
Van Vuren, D. 1982. Comparative ecology of bison and cattle in the Henry Mountains, Utah. p. 449-457. In: J.M. Peek and P.D. Dalke (eds.) Proc. Wildlife-Livestock Relationships Symp. 10. Univ. of Idaho Forest, Wildl. and Range Exp. Sta., Moscow, Idaho.

Ward, A.L., J.J. Cupal, A.L. Lea, C.A. Oakley, and R.W. Weeks. 1973. Elk behavior in relation to cattle grazing, forest recreation and traffic. Trans. North Amer. Wildl. and Natur. Resour. Conf. 38:327-337.

Ward, A.L., J.J. Cupal, G.A. Goodwind, and H.D. Morris. 1976. Effects of highway construction and use on big game populations. Fed. Highway Admin. Off. Res. and Dev. Environ. Div. Rep. FHWA-RD-76-174, Laramie, Wyo.

Ward, A.L., N.E. Fornwalt, S.E. Henry, and R.A. Hodorf. 1980. Effects of highway operation practices and facilities on elk, mule deer and pronghorn antelope. Fed. Highway Admin. Off. Res. and Dev. Environ. Div. Rep. FHWA-RD-79-143, Laramie Wyo.

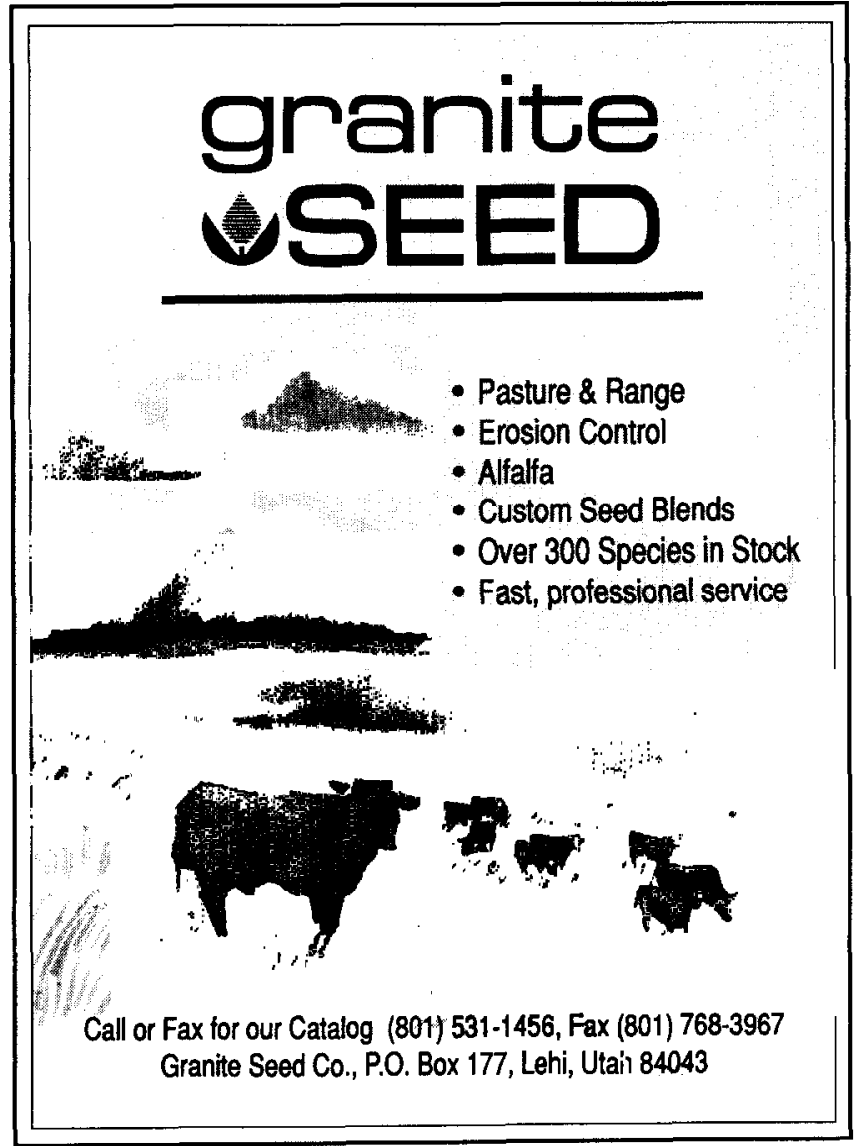

